\title{
Some carbonyl compounds and free fatty acid composition of Afyon Kaymagı (clotted cream) and their effects on aroma and flavor
}

\author{
By E. Şenel ${ }^{*}$ \\ Ankara University Faculty of Agriculture, Department of Dairy Technology, 06110, Ankara, Turkey. \\ (corresponding author: senel@agri.ankara.edu.tr)
}

\section{RESUMEN}

Composición de algunos compuestos carbonílicos y de los ácidos grasos libres de Afyon Kaymagi (cuajada) y sus efectos sobre el aroma y el sabor.

Se han investigado algunos compuestos carbonílicos (acetaldehido, acetona, 2-butanona y diacetil), el ácido láctico y la composición de los ácidos grasos libres de Afyon kaymagi (cuajada), producida sólo a partir de leche de búfalas obtenidas de siete granjas diferentes y sus efectos sobre el aroma y el sabor. Entre los compuestos carbonílicos, la acetona fué el que se encontró en mayor concentración. Butírico, esteárico, oleico, linoleico y linolénico son los ácidos grasos libres característicos de Afyon Kaymagı. El efecto de los compuestos investigados en las puntuaciones (AFS) de aroma y sabor de Afyon Kaymagı se encontró que fué del 93,3\%. El ácido láctico, segundo compuesto importante, se correlacionó negativamente con el aroma y el sabor de Afyon Kaymagı $(\mathrm{R} 2=40 \%)$. Los compuestos carbonilos investigados explican sólo el 3,2\% de la variación en el aroma y el sabor de Afyon Kaymagı. El ácido láctico, la acetona, diacetil, y los ácidos $\mathrm{C}_{4 \cdot 0}, \mathrm{C}_{8.0}, \mathrm{C}_{12.0}$ y $\mathrm{C}_{18.0}$ tienen un efecto negativo en la AFS, pero el acetaldehído, la 2-butanona, y los ácidos $\mathrm{C}_{6: 0}$, $\mathrm{C}_{10: 0}, \mathrm{C}_{14: 0}, \mathrm{C}_{16: 0}, \mathrm{C}_{18: 1}, \mathrm{C}_{18: 2}$ y $\mathrm{C}_{18: 3}$ están positivamente relacionados con el AFS.

PALABRAS CLAVE: Ácidos grasos libres - Ácido láctico - Afyon Kaymagr (cuajada) - Aroma y sabor - Compuestos carbonílicos.

\section{SUMMARY}

Some carbonyl compounds and free fatty acid composition of Afyon Kaymagı (clotted cream) and their effects on aroma and flavor.

Some carbonyl compounds (acetaldeyhde, acetone, butanone- 2 and diacetyl), the lactic acid and free fatty acid compositions of Afyon kaymagı, produced from pure buffalo milk obtained from seven different farms, and their effects on aroma and flavor were investigated. Acetone was found in the highest amount of carbonyl compounds. Butyric, stearic, oleic, linoleic and linolenic acids were characteristic free fatty acids for Afyon Kaymagı. The effect of the investigated compounds on the aroma and flavor scores (AFS) of Afyon Kaymagı was found to be $93.3 \%$. Lactic acid was negatively correlated but was the second most important compound for the aroma and flavor of Afyon Kaymagı $\left(R^{2}=40 \%\right)$. The investigated carbonyl compounds explained only $3.2 \%$ of the variation in aroma and flavor of Afyon Kaymagı. Lactic acid, acetone, diacetyl, $\mathrm{C}_{4: 0}, \mathrm{C}_{8: 0}, \mathrm{C}_{12: 0}$ and $\mathrm{C}_{18: 0}$ had negative effects on the AFS, but acetaldehyde, butanone-2, $\mathrm{C}_{6: 0}, \mathrm{C}_{10: 0}$,
$\mathrm{C}_{14: 0}, \mathrm{C}_{16: 0}, \mathrm{C}_{18: 1}, \mathrm{C}_{18: 2}$ and $\mathrm{C}_{18: 3}$ were positively related to the AFS.

KEY-WORDS: Afyon Kaymagı (clotted cream) - Aroma and flavor-Carbonyl compounds - Free fatty acids - Lactic acid.

\section{INTRODUCTION}

In recent years, the popularity of traditional dairy products has shown a steady increase throughout the world. There are two approaches to protecting the unique characteristic of dairy products and to preventing the production of imitation products: protected geographical indication (PGI) and protected designation of origin (PDO), which have become an important issue for the registration of traditional dairy products in the European Committee (Avşar et al., 2003). Traditional dairy products are very important in Anatolia culture, but many of them have recently been lost.

Clotted cream produced in the Afyon province is called Afyon Kaymagı, produced from pure water buffalo milk. This product has been registered by geographical indication as a traditional dairy product since 7.12.2005. Nowadays, the interest and investment in buffalo milk and its products have increased in many countries (Amarjit and Toshihiko, 2003). Its attraction arises from its nutrient content and aroma and flavor. Buffalo milk has a higher fat content as well as protein, lactose, total solids, mineral and vitamin contents along with a rich aroma and flavor when compared to cow's milk. Thus it makes a highly suitable ingredient for the manufacturing of some dairy products including cheese, ice cream and yoghurt (Siriken and Erol, 2009). In Turkey, buffalo milk is most commonly used for the manufacturing of Afyon Kaymagı, and to a lesser extent for the manufacturing of buffalo yoghurt. In the traditional way of Afyon Kaymagı, raw buffalo milk is bolted by cheesecloth twice and put into copper containers. Slow heating is applied to the raw milk and when the temperature reaches $90^{\circ} \mathrm{C}$ it is held for $30 \mathrm{~min}$. This stage is called "göbek bağlama". After this stage, the milk is left at room temperature overnight to cool. In the morning, the cream layer of the evening milk is released by 
perforating the side of the container with a pin. After the following morning's milking, milk is added to the heat treated cream obtained from the previous evening's milk. Then the mixture (evening and morning milks) is slowly heated to $90^{\circ} \mathrm{C}$ for $45 \mathrm{~min}$ for a second time. Then it is slowly cooled to room temperature and left in the cool room. It is kept by itself until noon if the season is summer or until the mid afternoon if it is winter. After this period, it is refrigarated until morning. Then the clotted cream layer is seperated by cutting. Finally it is inverted and packaged in a plastic can before sale. There is limited research about Afyon Kaymagı in the literature. One study, an international publication, is about the microbiological properties of Afyon Kaymagı (Siriken and Erol, 2009). In another study, the storage times of Afyon kaymagı in different packaging were determined (Çon et al., 2000). Tekissen and Gürler (2004) have also monitored the conventional method for the manufacturing of Afyon kaymagı. There is limited information about Afyon Kaymagı, with no available data about the chemical composition especially compounds which affect the aroma, flavor and self-life of Afyon kaymagı. The formation of aroma and flavor compounds is the result of the chemical and biochemical transformations of milk components (Kranenburg et al., 2002). These compounds may be divided into four main catagories: non-volatile acids (lactic, pruvic e.g.), volatile acids (formic, acetic and butyric e.g.), carbonyl compounds (acetaldehyde, acetone, diacetyl e.g.), miscellaneous compounds (certain amino acids, constituents formed by thermal degradation of protein, fat or lactose) (Tamime and Robinson, 2007). Carbonyles, lactic acid and free fatty acids, among the aroma and flavor compounds mentioned above, have an important effect on the shelf-life and formation of the characteristic aroma and flavor of dairy products.

The main purpose of this study is to determine the level of acetaldehyde, acetone, butanone-2, diacetyl, lactic acid and free fatty acids of Afyon Kaymagı produced from buffalo milk and the changes these compounds undergo during the storage time. A secondary purpose is to explain the variation in aroma and flavor scores of Afyon Kaymagı, taking into consideration the effect of these compounds.

\section{MATERIALS AND METHODS}

\subsection{Materials}

A total of 14 Afyon Kaymagı were produced from buffalo milk obtained from 7 different farms in the Afyon province, Turkey. The samples, in original plastic round containers of $300 \mathrm{~g}$ were transferred to the laboratory under cold storage conditions at $4-8^{\circ} \mathrm{C}$. The samples were analyzed on the first and seventh days of storage at $4^{\circ} \mathrm{C}$, since the self life of Afyon Kaymagı is approximately 1 week.

\subsection{Methods}

\section{Physico-chemical anaylses}

The fat content of the samples was determined by the Gerber method (Hooi et al., 2004). The dry matter of Afyon Kaymagı was determined by the oven drying method according to the methods used by Hooi et al., (2004). The titratable acidity of the samples was detected according to Hooi et al., (2004). The pH values were measured with a $\mathrm{pH}$-meter model Mettler Toledo (Analytical, Sonnenbergstrasse 74, CH-8603, Schwerzenback, Switzerland) fitted with a standard, combined glass electrode. The $\mathrm{pHs}$ in the serum of the samples were determined according to IDF (1981). The lactic acid values of the samples were measured using the spectrometric method (Steinholt and Calbert, 1960). The regression coefficients of standard curves were $R^{2}=0.99$ for lactic acid.

\section{Determination of carbonyl compounds}

Carbonyl compounds were determined by the headspace tecnique using gas chromatography (Ulbert, 1991). In the determination of carbonyl compounds, an Agilent Model 6890 Series GC System Plus gas chromatograph (Agilent Tech., Inc., 395 Page Mill Rd., Palo Alto, CA 94306, USA) fitted with an FID detector, was used. Volatiles were seperated with a capillary column of $30 \mathrm{~m} \times 320 \mu \mathrm{m}$ id (HP Innowax Polyethylene glycol, Model Agilent $19091 \mathrm{~N}-13)$. Nominal film thickness for the column was $0.25 \mu \mathrm{m}$. Operating conditions for $\mathrm{GC}$ analyses were as follows: EPC split-splitless inlet, injection temperature $80^{\circ} \mathrm{C}$, splitless, injection volume 1000 $\mu \mathrm{L}$; oven temperature was raised from $50^{\circ} \mathrm{C}$ to $70^{\circ} \mathrm{C}$ at a rate of $4^{\circ} \mathrm{C}$ per min. and held for $0.5 \mathrm{~min}$., from $70^{\circ} \mathrm{C}$ to $180^{\circ} \mathrm{C}$ at a rate of $20^{\circ} \mathrm{C}$ and held for $0.2 \mathrm{~min}$.; column flow rate $0.7 \mu \mathrm{L} / \mathrm{min}^{-1}$; detector temperature $250^{\circ} \mathrm{C}$; make up gas nitrogen, flow rate for make up gas $30 \mu \mathrm{L} \cdot \mathrm{min}^{-1}$, hydrogen flow rate $40 \mu \mathrm{L} \cdot \mathrm{min}^{-1}$, air flow rate $400 \mu \mathrm{L}$. $\mathrm{min}^{-1}$. The temperature of the gas-tight syringe was maintened at $70^{\circ} \mathrm{C}$. Crimp top headspace vials with $20 \mathrm{~mL}$ capacity were used for the GC analyses. Samples of $5 \mathrm{~g}$. were weighed into these vials and closed with the crimper. All vials were stored in the freezer at $-20^{\circ} \mathrm{C}$ until they were analyzed on the GC. Before the injection, vials were kept at $70^{\circ} \mathrm{C}$ for $30 \mathrm{~min}$. Then they were kept at room temperature $5 \mathrm{~min}$. and injected into the GC. The quantification of constituents was achieved by means of a computing integrator operated in the internal Standard mode. The slope of each standard curve was used as a factor for calculation. Coefficients of standard curves were $\mathrm{R}^{2}=0.935$ for acetaldehyde (75-07-0, Merck, Germany), $R^{2}=$ 0.931 for acetone (67-64-1, Merck, Germany), $R^{2}=$ 0.924 for butanone-2 (78-93-3, Merck, Germany), $R^{2}$ $=0.934$ for diacetyl (431-03-8, Merck, Germany).

\section{Determination of free fatty acids}

Free fatty acids in samples were analyzed by a GC system (Agilent 6890 series, Agilent Tech. Inc. 
CA, USA) according to the method of Deeth et al., (1983).

Extraction of free fatty acids: samples were weighed as $1.5 \mathrm{~g}$ for clotted cream. They were ground with $2.5 \mathrm{~g}$ of $\mathrm{Na}_{2} \mathrm{SO}_{4}$ and then, $5 \mathrm{~mL}$ of internal standard $\left(\mathrm{C}_{7^{-}}\right.$heptanoic acid, 622070, Altech, IL, USA) and $300 \mu \mathrm{L} \mathrm{H}_{2} \mathrm{SO}_{4}$ were added. The mixture was mixed thoroughly for $1 \mathrm{~min}$ and hexane $(5 \mathrm{~mL})$ was added. Samples were left to rest for $1 \mathrm{~h}$ before the liquid phase was extracted from the Biorad column with deactivated alumina. Each sample was eluted two times in each column. Then each column was washed with $5 \mathrm{~mL}$ hexane/ diethyl ether (1:1) two times and dried with 5 psi of air. Dried alumina containing free fatty acids was transferred to test tubes and $2 \mathrm{~mL}$ of $6 \%$ formic acid in ether were added. The mixture was centrifuged at 2000x g for $10 \mathrm{~min}$., the clear part was transferred to vials by Pasteur pipette and stored at $-18^{\circ} \mathrm{C}$ until the injection.

GC analysis: Operating conditions for GC were as follows; Detector: FID (Agilent Tech. Inc. CA, USA) at $260^{\circ} \mathrm{C}$, Column: Capillary $(30 \mathrm{~m}$ x $320 \mu \mathrm{m}$ id. With $0.25 \mu \mathrm{m}$ film thickness (HP-FFAP Agilent Tech. Inc. Model 19091F-433), Injection mode/ volume: Split $(1 / 10) 5 \mu \mathrm{L}$ at $250^{\circ} \mathrm{C}$, Flow rates: $\mathrm{H}_{2}$ : Air: $\mathrm{N} 2=33: 370: 30 \mathrm{~mL} \mathrm{~min}^{-1}$. Oven temperature: $120^{\circ} \mathrm{C}$ for $0 \mathrm{~min}$ increased to $200^{\circ} \mathrm{C}$ at a rate of $10^{\circ} \mathrm{C}$ per min then held at $200^{\circ} \mathrm{C}$ for $2 \mathrm{~min}$ and increased to $205^{\circ} \mathrm{C}$ at a rate of $10^{\circ} \mathrm{C}$ per min and held for $2 \mathrm{~min}$, then increased to $210^{\circ} \mathrm{C}$ at a rate of $10^{\circ} \mathrm{C}$ per $\mathrm{min}$ and held for $2 \mathrm{~min}$ then increased to $215^{\circ} \mathrm{C}$ at a rate of $10^{\circ} \mathrm{C}$ per min and held for 3 min and increased to $230^{\circ} \mathrm{C}$ at a rate of $10^{\circ} \mathrm{C}$ per $\mathrm{min}$ held for $3 \mathrm{~min}$. Standard mixture solutions were prepared in $6 \%(\mathrm{v} / \mathrm{v})$ formic acid in ether solution as in the sample preparation and $5 \mu \mathrm{L}$ injected into the GC system with the same conditions as the sample injection. FFA standards $\left(\mathrm{C}_{4: 0}, \mathrm{C}_{6: 0}, \mathrm{C}_{8: 0}\right.$, $\mathrm{C}_{10: 0}, \mathrm{C}_{12: 0}, \mathrm{C}_{14: 0}, \mathrm{C}_{16: 0}, \mathrm{C}_{18: 0}, \mathrm{C}_{18: 1}, \mathrm{C}_{18: 2}, \mathrm{C}_{18: 3}$ ) were chromatographic grade supplied by Alltech Assos. (IL, USA). Quantification of the constituents was achieved by means of either external or internal standard mode.

\section{Sensory evaluation}

The sensory properties of the samples were evaluated according to Atamer and Sezgin (1984). The panel consisted of ten experienced panelists (five female and five male) from the academic staff working in the Dairy Department. The panel evaluated samples in terms of aroma and flavor, using a ten point scale $(10=$ excellent; $9=$ good; $8=$ just right; $7=$ light off flavor; $4=$ clear off flavor; $1=$ strong off flavor). Panel also described the off flavor if they gave below 8 points to a sample. Defined off flavors are; metallic, rancid, cheesy, extremely acidic, extremely sour, flat, feedy, cooked, milky, others. The ages of fifty percent of panelists ranged from 45-55, twenty percent from 40-45 and thirty percent from 25-35 years old. The panel was trained for 1 hour before each evaluation session. Some sensory terms for flavor and aroma of Afyon kaymagı were introduced to panelists. Samples were left at room temperature for 5 minutes. Then they were served to the panelists with a glass of water and an unsalted cracker. Samples were presented on 3 digit coded glass plates. All samples were presented at the same time in each session. Sensory evaluation of samples was carried out two times.

\section{Statistical analysis}

SPSS 13.0 for Windows statistic package was used for statistical analyses. First, the KolmogrovSmirnov test was applied to the whole data if the results showed normal distribution or not. Data were calculated by descriptive statistics. The T-test was used to compare the differences among storage days. The correlations between investigated properties of Afyon kaymagı were deternined on both the $1^{\text {st }}$ and $7^{\text {th }}$ day of storage (Rosner, 2006). In addition to investigating the relationship between aroma and flavor scores and independent variables, the multiple regression analysis was applied. A path analysis was used to explore the individual direct effect of these compounds. Regression analysis also provided information on the variation of dependent variables explained by the independent variables. The multiple regression equation is shown below (Draper and Smith, 1998).

$$
\text { Equation: } Y i=\beta_{0}+\beta_{1} X_{1 i}+\beta_{2} X_{2 i}+\ldots+\beta_{k} X_{k i}+\varepsilon_{i}
$$

\section{RESULTS AND DISCUSSION}

\subsection{Fat, dry matter, $\mathrm{pH}$ in serum and titratable acidity}

Some general properties of Afyon Kaymagı are shown in Table 1. The mean value of fat, total dry matter, non fat dry matter, $\mathrm{pH}$ in serum and titratable acidity were found as $58 \pm 1.43$, $65.92 \pm 1.17,8.28 \pm 0.67,6.42 \pm 0.25,3.53 \pm 0.91$, respectively. Non fat dry matter was calculated using the values of fat and total dry matter.

\subsection{Some carbonyl compounds (acetaldehyde, acetone, butanone-2, diacetyl) and lactic acid}

Acetaldehyde, acetone, butanone-2, diacetyl and lactic acid contents of Afyon kaymagı during storage are given in Table 2.

The acetaldehyde levels of the samples were determined as between trace and $4.50 \mathrm{mg} \mathrm{kg}^{-1}$ on the first day. Although acetaldehyde is one of the major carbonyl compounds influencing the characteristic aroma and flavor of yoghurt (Vedamuthu, 2006), it contributes to the formation of aroma and flavor in butter and cream products (Tamime and Robinson, 2007). In this study, the level of acetaldehyde in samples was lower than that of fermented dairy products, especially yoghurt (Beshkova et al., 1998). 
Table 1

Some properties of Afyon Kaymagı

\begin{tabular}{|c|c|c|c|c|c|}
\hline & $\begin{array}{c}\text { Fat } \\
\left(\mathrm{mg} \mathrm{100g}^{-1}\right)\end{array}$ & $\begin{array}{l}\text { Total dry matter } \\
\left(\mathrm{mg} \mathrm{100g}^{-1}\right)\end{array}$ & $\begin{array}{l}\text { Nonfat dry matter } \\
\quad\left(\mathrm{mg} \mathrm{100g}^{-1}\right)\end{array}$ & $\begin{array}{c}\text { pH } \\
\text { in Serum }\end{array}$ & $\begin{array}{c}\text { Titratable acidity } \\
\left(\mathrm{SH}^{\circ}\right)\end{array}$ \\
\hline 1 & 56 & 65.29 & 9.29 & 6.52 & 3.67 \\
\hline 2 & 59 & 65.48 & 6.48 & 6.54 & 3.52 \\
\hline 3 & 57 & 65.51 & 8.51 & 6.65 & 2.80 \\
\hline 4 & 58 & 65.94 & 7.94 & 6.74 & 2.45 \\
\hline 5 & 60 & 65.81 & 5.81 & 6.68 & 2.41 \\
\hline 6 & 58 & 64.41 & 6.41 & 6.57 & 3.11 \\
\hline 7 & 56 & 65.77 & 9.77 & 6.05 & 4.91 \\
\hline 8 & 56 & 64.81 & 8.81 & 6.12 & 4.52 \\
\hline 9 & 59 & 65.76 & 6.79 & 6.44 & 3.63 \\
\hline 10 & 58 & 65.61 & 7.61 & 6.23 & 3.86 \\
\hline 11 & 58 & 65.00 & 7.00 & 6.13 & 4.64 \\
\hline 12 & 58 & 68.35 & 10.35 & 6.03 & 4.81 \\
\hline 13 & 60 & 66.73 & 6.73 & 6.60 & 2.67 \\
\hline 14 & 60 & 68.42 & 8.42 & 6.58 & 2.42 \\
\hline Min & 56 & 64.41 & 5.81 & 6.03 & 2.41 \\
\hline Max & 60 & 68.42 & 15.77 & 6.79 & 4.91 \\
\hline Mean & $58 \pm 0.38$ & $65.92 \pm 1.17$ & $8.28 \pm 0.67$ & $6.42 \pm 0.25$ & $3.53 \pm 0.91$ \\
\hline
\end{tabular}

Table 2

Some carbonyl compounds and lactic acid of Afyon Kaymagı

\begin{tabular}{ccccccccccc}
\hline & \multicolumn{2}{c}{$\begin{array}{c}\text { Acetaldehyde } \\
\left(\mathrm{mg} \mathrm{kg}^{-1}\right)\end{array}$} & \multicolumn{2}{c}{$\begin{array}{c}\text { Acetone } \\
\left(\mathrm{mg} \mathrm{kg}^{-1}\right)\end{array}$} & $\begin{array}{c}\text { Butanone-2 } \\
\left(\mathrm{mg} \mathrm{kg}^{-1}\right)\end{array}$ & \multicolumn{2}{c}{$\begin{array}{c}\text { Diacetyl } \\
\left(\mathrm{mg} \mathrm{kg}^{-1}\right)\end{array}$} & $\begin{array}{c}\text { Lactic acid } \\
\left(\mathbf{g} 100 \mathbf{g}^{-1}\right)\end{array}$ \\
\hline Samples & day 1 & day 7 & day 1 & day 7 & day 1 & day 7 & day 1 & day 7 & day 1 & day 7 \\
\hline 1 & 2.33 & 3.87 & 5.54 & 6.20 & 0.71 & 1.11 & 4.11 & 8.65 & 0.38 & 0.62 \\
2 & 2.45 & 1.61 & 5.85 & 4.75 & trace & 2.26 & trace & 4.29 & 0.38 & 0.60 \\
3 & 1.39 & 0.82 & 6.23 & 7.06 & trace & trace & trace & trace & 0.38 & 0.48 \\
4 & 1.94 & 1.13 & trace & 4.08 & 0.70 & trace & trace & trace & 0.36 & 0.51 \\
5 & trace & 1.35 & 4.64 & 3.64 & 0.80 & trace & trace & 3.60 & 0.39 & 0.48 \\
6 & 4.50 & 4.42 & 7.73 & 7.43 & 0.32 & 0.90 & 3.83 & 5.71 & 0.38 & 0.57 \\
7 & 1.31 & 2.16 & 6.11 & 5.02 & trace & trace & trace & trace & 0.36 & 0.31 \\
8 & 1.43 & 3.22 & 6.11 & 7.46 & 0.30 & trace & 3.27 & 1.62 & 0.36 & 0.43 \\
9 & 1.16 & trace & 6.06 & 4.12 & trace & 0.83 & 2.28 & 1.83 & 0.36 & 0.44 \\
10 & 0.92 & trace & 5.11 & 6.05 & trace & 0.37 & trace & trace & 0.37 & 0.48 \\
11 & 0.58 & 0.40 & 4.96 & 4.94 & 0.86 & trace & 1.65 & 6.18 & 0.35 & 0.30 \\
12 & 0.34 & 0.74 & 5.02 & 3.98 & 0.43 & trace & 1.77 & 1.63 & 0.36 & 0.50 \\
13 & trace & 0.95 & 6.72 & 4.96 & 1.54 & 0.76 & trace & 3.72 & 0.35 & 0.44 \\
14 & trace & 4.71 & 6.94 & 10.03 & 2.18 & 0.79 & trace & 1.98 & 0.36 & 0.47 \\
\hline Min & trace & trace & trace & 3.64 & trace & trace & trace & trace & 0.35 & 0.30 \\
\hline Max & 4.50 & 4.71 & 7.73 & 7.15 & 2.18 & 2.26 & 4.11 & 8.65 & 0.39 & 0.62 \\
\hline Mean & $1.31 \pm 0.32$ & $1.81 \pm 0.43$ & $5.50 \pm 0.47$ & $5.69 \pm 0.48$ & $0.56 \pm 0.17$ & $0.51 \pm 0.17$ & $1.21 \pm 0.42$ & $2.80 \pm 0.71$ & $0.37 \pm 0.00$ & $0.47 \pm 0.02$ \\
\hline
\end{tabular}


But the acetaldehyde content of the samples was close to that of butter. The acetaldehyde level in Yayık butter produced from yoghurt is 2.26-10.01 $\mathrm{mg} \mathrm{kg}^{-1}$ and that of cream butters is $0.95-2.81 \mathrm{mg}$ $\mathrm{kg}^{-1}$ as noted by Şenel (2006). It is well known that acetaldehyde in dairy products is obtained from lactose and amino acids as a result of the metabolic activity of lactic acid bacteria (Chaves et al., 2002; Tamime and Robinson, 2007). The first reason could be attributed to the fact that Afyon kaymagı is a product with a high fat content. The second reason could be that stater culture was not used in the manufacturing. Because of these reasons, the acetaldehyde level in the samples could be lower. The acetaldehyde level showed irregular changes during storage. In $50 \%$ of the samples, the acetaldehyde content increased, and in $35.71 \%$ of the samples it decreased. In $14.29 \%$ of the samples, the acetaldehyde level remained fairly constant during storage. In the literature, while some researchers reported that the acetaldehyde level in various fermented products decreased during storage (Beshkova et al., 1998; Şenel et al., 2009), others observed that it increased (Şenel, 2000). The decrease in the level of acetaldehyde during storage could be attributed to the fact that acetaldehyde can be easily oxidized to acetate, leading to decreasing levels during storage (Tamime and Robinson, 2007).

The acetone content of samples varied from trace amounts to $7.73 \mathrm{mg} \mathrm{kg} \mathrm{m}^{-1}$ on the first day. Acetone was found in the highest amount among all carbonyl compounds. Acetone is produced from a lactose transformation and also from degradation by the heating of fat (Frank and Marth, 1999). The main reason for the high amount of acetone in samples could be attributed to applying a double heat treatment $\left(90^{\circ} \mathrm{C}\right.$ for $30 \mathrm{~min}$.) which is called cooking in the manufacturing of Afyon Kaymag. The acetone level in only two samples showed an evident increase during storage, but in the other samples it was generally unchanged.

Butanone-2 in samples was detected between trace amounts and $2.18 \mathrm{mg} \mathrm{kg}^{-1}$ on the first day. The butanone- 2 content in 5 of the 14 samples on the first day and in 7 of the 14 samples on the $7^{\text {th }}$ day of storage was found to be in trace amounts. Butanone-2 in some dairy products such as yoghurt, yayık butters and cream butters were detected in trace amounts (Atamer et al., 2004a; Atamer et al., 2004b). The level of butanone-2 in the samples showed irregular changes during storage. In general, the butanone-2 contents showed a decresing tendency during storage. While butanone-2 increased in five samples, it was fairly constant in two samples. Butanone-2 in dairy products is formed during lactose fermentation by lactic acid bacteria, and also by fat degradation (Rasic and Kurmann, 1978). It could be attributed to the fact that a stater culture was not used in the manufacturing of Afyon kaymagı.

Diacetyl was found between trace amounts and $4.11 \mathrm{mg} \mathrm{kg}^{-1}$ on the first day. In 8 of the 14 samples, diacetyl was detected on the first day and in 4 of the 14 samples it was detected on the seventh day in trace amounts. While diacetyl amounts in 7 of the 14 samples increased during storage, in one of them it decreased. These changes were found statistically significant $(P<0.05)$. The diacetyl amount in 5 samples was unchanged during storage but in 4 of them there were trace amounts on both storage days. Rasic and Kurman (1978) stated that the desired aroma and flavor in butter is formed even if diacetyl is in low amounts (0.9 $\left.\mathrm{mg} \mathrm{kg}^{-1}\right)$. The amount of diacetyl in cultured cream butter was reported as $0.5-2.0 \mathrm{mg} \mathrm{kg}^{-1}$ by the work of Spreer (1998).

Lactic acid in the samples varied from 0.35 to

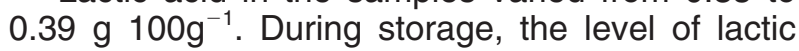
acid increased in all samples. This increase was statistically significant $(P<0.001)$. The lactic acid level in both storage periods was lower than other fermented dairy products since a starter culture is normally not used in the manufacturing of Afyon Kaymagı.

\subsection{Free fatty acid composition (FFAs)}

The short-chain free fatty acids (from $\mathrm{C}_{4: 0}$ to $\mathrm{C}_{10: 0}$ ) of Afyon Kaymagı during storage are given in Table 3. The mean value of butyric acid $\left(\mathrm{C}_{4: 0}\right)$, caproic acid $\left(\mathrm{C}_{6: 0}\right)$, caprylic acid $\left(\mathrm{C}_{8: 0}\right)$ and capric acid $\left(\mathrm{C}_{10: 0}\right)$ were found to be $53.48 \pm 9.35,20.69 \pm 3.10,8.21 \pm 1.58$, $17.41 \pm 3.21 \mathrm{mg} \mathrm{kg}^{-1}$ respectively. Butyric acid, among four free fatty acids $\left(\mathrm{C}_{4: 0}, \mathrm{C}_{6: 0}, \mathrm{C}_{8: 0}\right.$ and $\left.\mathrm{C}_{10: 0}\right)$, was predominant in Afyon Kaymagı. The total amounts of short-chain free fatty acids have been determined as $99.79 \mathrm{mg} \mathrm{kg}^{-1}$ on the first day and as $74.64 \mathrm{mg} \mathrm{kg}^{-1}$ on the $7^{\text {th }}$ day (see Table 6).

The medium-long chain free fatty acids (from $\mathrm{C}_{12: 0}$ to $\mathrm{C}_{18: 0}$ ) of Afyon Kaymagı during storage are given in Table 4. The mean value of lauric acid $\left(\mathrm{C}_{12: 0}\right)$, myristic acid $\left(\mathrm{C}_{14: 0}\right)$, palmitic acid $\left(\mathrm{C}_{16: 0}\right)$ and stearic acid $\left(\mathrm{C}_{18: 0}\right)$ were determined as $27.27 \pm 4.55,198 \pm 26.90$, $1124 \pm 131,1253 \pm 157 \mathrm{mg} \mathrm{kg}^{-1}$, respectively. Palmitic and stearic acids, among medium-long chain free fatty acids, were determined to be the highest in Afyon Kaymagı. The total amount of medium-long chain free fatty acids was found to be $2602.27 \mathrm{mg}$ $\mathrm{kg}^{-1}$ on the first day and $2183.32 \mathrm{mg} \mathrm{kg}^{-1}$ on the $7^{\mathrm{th}}$ day (see Table 6).

The unsaturated free fatty acids (from $C_{18: 1}$ to $C_{18: 3}$ ) of Afyon Kaymagı during storage are given in Table 5 . The mean values of oleic $\left(\mathrm{C}_{18: 1}\right)$, linoleic $\left(\mathrm{C}_{18: 2}\right)$, linolenic $\left(C_{18: 3}\right)$ were $1655 \pm 223,176.20 \pm 22.80$, $154.90 \pm 48.20 \mathrm{mg} \mathrm{kg}^{-1}$, respectively. Oleic acid, among the unsaturated free fatty acids, was predominant in Afyon Kaymagı. The total amount of unsaturated free fatty acids was found to be 1986.10 $\mathrm{mg} \mathrm{kg}^{-1}$ on the first day and $2276.10 \mathrm{mg} \mathrm{kg}^{-1}$ on the $7^{\text {th }}$ day (sees Table 6).

As can be seen in Tables 3, 4 and 5, there was generally a relatively wide range between the minimum and maximum values of individual free fatty acids in both storage times. In this study, Afyon Kaymagı samples were obtained from primitive dairy farms or plants in which they were traditionally produced. 
Table 3

Short chain free fatty acid composition $\left(\mathrm{C}_{4: 0}-\mathrm{C}_{10: 0}\right)$ of Afyon Kaymagı $\left(\mathrm{mg} \mathrm{kg}^{-1}\right)$

\begin{tabular}{ccccccccc}
\hline & \multicolumn{2}{c}{ Butyric acid $\left(\mathbf{C}_{4: 0}\right)$} & \multicolumn{2}{c}{ Caproic acid $\left(\mathbf{C}_{6: 0}\right)$} & \multicolumn{2}{c}{ Caprylic acid $\left(\mathbf{C}_{8: 0}\right)$} & \multicolumn{2}{c}{ Capric acid $\left(\mathbf{C}_{10.0}\right)$} \\
\hline 1 & $\mathbf{1}$ day & $\mathbf{7}$ day & $\mathbf{1}$ day & $\mathbf{7}$ day & $\mathbf{1}$ day & $\mathbf{7}$ day & $\mathbf{1}$ day & $\mathbf{7}$ day \\
\hline 2 & 51.00 & 19.98 & 18.55 & 6.43 & 5.80 & 2.98 & 11.93 & 8.03 \\
3 & 55.45 & 13.31 & 18.84 & 6.80 & 5.38 & 1.61 & 10.64 & 3.27 \\
4 & 80.85 & 87.56 & 32.03 & 20.73 & 13.1 & 19.09 & 32.80 & 41.61 \\
5 & 10.26 & 14.20 & 6.71 & 6.90 & 1.41 & 2.12 & 2.91 & 4.12 \\
6 & 107.12 & 37.10 & 33.80 & 8.84 & 11.90 & 5.72 & 26.97 & 13.7 \\
7 & 65.70 & 11.59 & 25.57 & 5.31 & 10.41 & 2.59 & 19.70 & 6.17 \\
8 & 75.66 & 32.14 & 28.40 & 9.72 & 10.46 & 12.34 & 26.75 & 29.22 \\
9 & 85.76 & 13.56 & 36.05 & 7.12 & 16.76 & 4.85 & 32.27 & 11.7 \\
10 & 67.04 & 24.30 & 27.85 & 11.85 & 12.13 & 11.24 & 24.08 & 22.11 \\
11 & 11.14 & 62.67 & 5.86 & 18.48 & 2.10 & 13.41 & 5.43 & 21.64 \\
12 & 12.97 & 30.79 & 6.64 & 14.82 & 2.66 & 11.96 & 6.41 & 17.86 \\
13 & 13.61 & 16.86 & 7.98 & 7.60 & 1.93 & 2.67 & 4.00 & 6.54 \\
\hline 14 & 14.16 & 18.72 & 8.48 & 8.68 & 2.12 & 3.27 & 5.05 & 7.68 \\
\hline Min & 10.26 & 11.59 & 5.86 & 5.31 & 1.41 & 1.61 & 2.91 & 3.27 \\
\hline Max & 107.12 & 121.42 & 36.05 & 30.99 & 18.81 & 26.56 & 34.82 & 61.16 \\
\hline Mean & $53.48 \pm 9.35$ & $36.11 \pm 8.73$ & $20.69 \pm 3.10$ & $11.73 \pm 1.94$ & $8.21 \pm 1.58$ & $8.60 \pm 2.01$ & $17.41 \pm 3.21$ & $18.20 \pm 4.40$ \\
\hline
\end{tabular}

Table 4

Medium-long chain free fatty acid composition $\left(\mathrm{C}_{12: 0^{-}} \mathrm{C}_{18: 0}\right)$ of Afyon Kaymagı $\left(\mathrm{mg} \mathrm{kg}^{-1}\right)$

\begin{tabular}{ccccccccc}
\hline & \multicolumn{2}{c}{ Lauric acid $\left(\mathbf{C}_{12: 0}\right)$} & \multicolumn{2}{c}{ Mrystic acid $\left(\mathbf{C}_{14: 0}\right)$} & \multicolumn{2}{c}{ Palmitic acid $\left(\mathbf{C}_{16: 0}\right)$} & \multicolumn{2}{c}{ Stearic acid $\left(\mathbf{C}_{18: 0}\right)$} \\
day $\mathbf{1}$ & day $\mathbf{7}$ & day $\mathbf{1}$ & day $\mathbf{7}$ & day $\mathbf{1}$ & day $\mathbf{7}$ & day $\mathbf{1}$ & day $\mathbf{7}$ \\
\hline 1 & 21.61 & 13.56 & 181.74 & 104.01 & 1275.02 & 711.25 & 1351.63 & 743.11 \\
2 & 20.08 & 7.23 & 177.09 & 70.30 & 1233.59 & 508.93 & 1426.99 & 611.39 \\
3 & 47.02 & 45.26 & 310.73 & 236.32 & 1429.69 & 885.61 & 2172.49 & 1451.38 \\
4 & 53.36 & 74.58 & 300.91 & 422.01 & 1476.08 & 1781.86 & 2034.17 & 2053.74 \\
5 & 6.39 & 8.44 & 61.18 & 82.88 & 443.83 & 512.69 & 662.78 & 710.40 \\
6 & 40.73 & 20.74 & 290.17 & 145.29 & 1688.96 & 922.68 & 1570.77 & 939.38 \\
7 & 30.67 & 8.61 & 226.34 & 62.61 & 1242.85 & 400.97 & 1261.43 & 590.39 \\
8 & 37.27 & 26.83 & 259.38 & 144.24 & 1430.92 & 733.08 & 1506.55 & 770.76 \\
9 & 48.81 & 17.56 & 334.74 & 121.73 & 1811.04 & 740.35 & 1738.9 & 942.73 \\
10 & 38.51 & 25.95 & 280.38 & 154.67 & 1506.84 & 864.35 & 1649.78 & 1098.67 \\
11 & 9.47 & 33.59 & 78.88 & 255.94 & 530.63 & 1615.32 & 590.35 & 1356.55 \\
12 & 11.01 & 35.89 & 89.05 & 324.43 & 581.85 & 2365.70 & 645.93 & 1769.58 \\
13 & 7.18 & 11.11 & 69.05 & 101.02 & 447.04 & 758.11 & 434.67 & 878.69 \\
14 & 9.73 & 12.46 & 112.37 & 601.22 & 636.22 & 106.22 & 489.34 & 579.61 \\
\hline Min & 6.39 & 7.23 & 61.18 & 62.61 & 443.83 & 106.22 & 434.67 & 579.61 \\
\hline Max & 53.36 & 74.58 & 334.70 & 601.20 & 1811.04 & 2365.70 & 2172.49 & 2053.74 \\
\hline Mean & $27.27 \pm 4.55$ & $24.42 \pm 4.96$ & $198.00 \pm 26.90$ & $201.90 \pm 41.50$ & $1124 \pm 131$ & $922 \pm 161$ & $1253 \pm 157$ & $1035 \pm 123$ \\
\hline & & & & & & & & \\
\hline
\end{tabular}


Table 5

Unsaturated free fatty acid composition $\left(\mathrm{C}_{18: 1}-\mathrm{C}_{18: 3}\right)$ of Afyon Kaymagı $\left(\mathrm{mg} \mathrm{kg}^{-1}\right)$

\begin{tabular}{ccccccc}
\hline \multirow{2}{*}{ Samples } & \multicolumn{2}{c}{ Oleic acid $\left(\mathbf{C}_{18: 1}\right)$} & \multicolumn{2}{c}{ Linoleic acid $\left(\mathbf{C}_{18: 2}\right)$} & \multicolumn{2}{c}{ Linolenic acid $\left(\mathbf{C}_{18: 3}\right)$} \\
& day $\mathbf{~ d ~}$ & day $\mathbf{7}$ & day $\mathbf{1}$ & day $\mathbf{7}$ & day $\mathbf{1}$ & day $\mathbf{7}$ \\
\hline 1 & 1465.97 & 1238.96 & 198.78 & 165.70 & 146.74 & 45.72 \\
2 & 1533.30 & 699.78 & 185.70 & 78.13 & 192.24 & 16.35 \\
3 & 2777.63 & 2843.12 & 323.82 & 342.35 & 544.98 & 176.19 \\
4 & 2670.51 & 4262.79 & 269.55 & 476.67 & 523.21 & 216.53 \\
5 & 641.61 & 961.09 & 72.78 & 11.74 & 67.12 & 25.04 \\
6 & 2286.99 & 1650.44 & 282.06 & 228.62 & 318.81 & 62.56 \\
7 & 2395.20 & 937.66 & 166.98 & 126.06 & 47.65 & 27.77 \\
8 & 2420.08 & 2234.31 & 257.56 & 261.74 & 74.5 & 75.45 \\
9 & 2264.14 & 1994.34 & 177.87 & 188.44 & 70.91 & 46.32 \\
10 & 2043.38 & 2340.08 & 187.99 & 246.25 & 86.67 & 68.38 \\
11 & 643.26 & 2630.64 & 93.51 & 408.8 & 18.72 & 51.88 \\
12 & 695.12 & 2975.90 & 100.24 & 396.68 & 11.35 & 46.12 \\
13 & 640.63 & 1666.03 & 49.94 & 149.72 & 23.71 & 59.01 \\
\hline 14 & 834.37 & 1276.35 & 99.61 & 104.72 & 42.54 & 57.68 \\
\hline Min. & 641.61 & 699.78 & 49.94 & 11.74 & 11.35 & 16.35 \\
\hline Max. & 2777.63 & 4262.79 & 323.82 & 476.67 & 544.98 & 216.53 \\
\hline Mean & $1655 \pm 223$ & $1979 \pm 263$ & $176.20 \pm 22.80$ & $227.50 \pm 36.60$ & $154.90 \pm 48.20$ & $69.60 \pm 15.20$ \\
\hline
\end{tabular}

Table 6

\begin{tabular}{|c|c|c|}
\hline \multicolumn{3}{|c|}{ Free fatty acid composition of Afyon Kaymagı $(n=14)\left(\mathrm{mg} \mathrm{kg}^{-1}\right)$} \\
\hline & $1^{\text {st }}$ dayof storage & $7^{\text {th }}$ dayof storage \\
\hline Butyric acid $\left(\mathrm{C}_{4}\right)$ & $53.48 \pm 9.35$ & $36.11 \pm 8.73$ \\
\hline Caproic acid $\left(\mathrm{C}_{6}\right)$ & $20.69 \pm 3.10$ & $11.73 \pm 1.94$ \\
\hline Caprylic acid $\left(\mathrm{C}_{8}\right)$ & $8.21 \pm 1.58$ & $8.60 \pm 2.01$ \\
\hline Capric acid $\left(\mathrm{C}_{10}\right)$ & $17.41 \pm 3.21$ & $18.20 \pm 4.40$ \\
\hline$\Sigma \mathbf{C}_{4: 0}-\mathbf{C}_{10: 0}$ & 99.79 & 74.64 \\
\hline Lauric acid $\left(\mathrm{C}_{12: 0}\right)$ & $27.27 \pm 4.55$ & $24.42 \pm 4.96$ \\
\hline Mrystic acid $\left(\mathrm{C}_{14: 0}\right)$ & $198.00 \pm 26.90$ & $201.90 \pm 41.50$ \\
\hline Palmitic acid $\left(\mathrm{C}_{16: 0}\right)$ & $1124 \pm 131$ & $922 \pm 161$ \\
\hline Stearic acid $\left(\mathrm{C}_{18: 0}\right)$ & $1253 \pm 157$ & $1035 \pm 123$ \\
\hline$\Sigma C_{12: 0}-C_{18: 0}$ & 2602.27 & 2183.32 \\
\hline Oleic acid $\left(\mathrm{C}_{18: 1}\right)$ & $1655 \pm 223$ & $1979 \pm 263$ \\
\hline Linoleic acid $\left(\mathrm{C}_{18: 2}\right)$ & $176.20 \pm 22.80$ & $227.50 \pm 36.60$ \\
\hline Linolenic acid $\left(\mathrm{C}_{18: 3}\right)$ & $154.90 \pm 48.20$ & $69.60 \pm 15.20$ \\
\hline$\Sigma C_{18: 1}-C_{18: 3}$ & 1986.10 & 2276.10 \\
\hline $\begin{array}{l}\text { Total free fatty acids } \\
\Sigma C_{4: 0}-C_{18: 3}\end{array}$ & 4688.16 & 4534.06 \\
\hline
\end{tabular}

Thefore, some samples may be contaminated with microorganisms especially yeast and mould, which produce lipase. Moulds can produce many different metabolites, including enzymes and organic acids
(Cousin, 2003). Although moulds are generally associated with the spoilage of cheeses, the spoilage of yoghurt, butter, cream and other dairy products is also occasionally caused by mould growth. Thus, 
poor sanitation and contamination with air in the dairy plant can cause an increase in the level of the mould spoilage of butter by the lipase-producing species Aspergillus, Cladosporium, Geotrichum and Penicillium (Cousin, 2003). Therefore, it could be concluded that poor sanitation conditions and mould contamination might cause big differences between minimum and maximum values of free fatty acids in the samples.

The total amount of free fatty acids (from $\mathrm{C}_{12: 0}$ to $\mathrm{C}_{18: 0}$ ) in Afyon Kaymagı was significantly higher than those of short-chain and unsaturated free fatty acids (see Table 6). In milk, fat is present in the form of globules, which are surrounded by their own membrane. The membrane triglycerides have a predominantly high melting point (Mulder and Walstra, 1974). In addition, the arrangement of tryglycerides in fat globules is mainly dependent on their melting point. On cooling or at physical ripening (crystalization), high melting glycerides form concentric crystalline layers on the innermost side of the fat globules, whereas low melting glycerides (liquid fat) are located at the core of globules (Marshall and Arbuckle, 2000). Therefore, high melting glycerides are considered to be easily affected by lipases (Şenel et al., 2011). A similar result has been reported by Şenel (2006) and Atamer et al., (2005) who explained that the accumulation of free fatty acids from triglycerides was higher in $\Sigma \mathrm{C}_{12: 0}-\mathrm{C}_{18: 0}$ than in other groups ( $\Sigma$ $\mathrm{C}_{4: 0}-\mathrm{C}_{10: 0}$ and $\left.\Sigma \mathrm{C}_{18: 1}-\mathrm{C}_{18: 2}\right)$ during the storage of Yayık butter samples.

Generally, the total amount of free fatty acids in Afyon Kaymagı decreased during storage. Although the level of butyric, caproic, lauric, palmitic, stearic and linolenic acids in samples decreased, the level of caprylic, capric myristic, oleic and linoleic acids in samples increased. The decrease in caproic and linolenic acid in the samples was found statistically significant $(P<0.05)$. The decrease in the level of FFA may be associated with the catabolism of FFA by microorganisms. It is well-known that catabolism is a very important biochemical process in the formation of the characteristic aroma and flavor of some cheeses (especially blue-mould cheese). Some moulds (such as Penicillium roqueforti) are responsible for the $\beta$-oxidation of FFA to produce methyl ketones and for the subsequent reduction to secondary alcohols (Fox et al., 2000). In the literature, it is reported that there are increases and decreases in the levels of FFA in various dairy products. Abd Rabo et al., (1992) determined that fatty acids from $\mathrm{C}_{6}$ to $\mathrm{C}_{12}$ decreased while those from $C_{14}$ to $C_{18: 2}$ increased during fermentation in the production of goat's milk yoghurt. Formisano et al., (1972) observed that FFA levels in yoghurt increased (significantly or moderately) over a period of 20 days in cold storage. Menéndez et al., (2000) noted a decrease in the volatile free fatty acid due to the oxidation of volatile free fatty acids or alternatively, to the formation of esters with alcohols produced as a result of the metabolism of lactic acid bacteria.

\subsection{Aroma and flavor}

The aroma and flavor scores of Afyon Kaymagı according to sensory evaluation are given in Figure 1. It was observed that storage time affected the aroma and flavor of Afyon Kaymagı. The aroma and flavor scores (AFS) of the samples decreased from $8.17 \pm 1.14$ to $5.52 \pm 0.55$ at the end of the $7^{\text {th }}$ day. This decrease during storage was found significant $(P<0.001)$. On the seventh day, some aroma and flavor defects such as bitter, cheesy, creamy and feedy were perceived by some of the panelist.

The results of the path analysis are given in Table 7. The total effect of the investigated compounds on the aroma and flavor scores of Afyon Kaymagı was found as $93.3 \%$. This effect was found significant $(P<0.001)$. The regression equation for AFS of Afyon Kaymagı is given in Equation 1.

Equation 1:

AFS $=0.0-0.18 \mathrm{LA}+0.12 \mathrm{AA}-0.374 \mathrm{AC}-$ $0.16 \mathrm{BU}-0.093 \mathrm{DC}-1.94 \mathrm{C} 4+2.83 \mathrm{C}_{6}-0.569 \mathrm{C}_{8: 0}$ $+1.53 C_{10: 0}-2.40 C_{12: 0}+0.133 C_{14: 0}+0.664 C_{16: 0}-$ $0.673 C_{18: 0}-0.403 C_{18: 1}+0.683 C_{18: 2}+0.248 C_{18: 3}$

(LA:lactic acid, AA:acetaldehyde, AC:acetone, BU: butanone-2, DC:diacetyl)

According to this equation, lactic acid, acetone, diacetyl, $\mathrm{C}_{4: 0}, \mathrm{C}_{8: 0}, \mathrm{C}_{12: 0}, \mathrm{C}_{18: 0}$ had a negative effect on the AFS, which means that these compounds were responsible for the deterioration of aroma and flavor. However, the remaining compounds were positively related to the AFS, which means that an increment in these compounds caused an improvement in the aroma and flavor of Afyon Kaymagı.

The results of the path analysis verified that free fatty acids explained $82.9 \%$ of the variation in AFS (see Table 7). That means free fatty acids had the most important effect on AFS. This effect was found statistically significant $(P<0.001)$. However, the effects of individual free fatty acids, except for $\mathrm{C}_{10: 0}$, on the aroma and flavor of Afyon Kaymagı were not found statistically significant $(P>0.05)$. $\mathrm{C}_{10: 0}$ was negatively related to AFS $(P<0.05)$. The individual effect of $\mathrm{C}_{10: 0}$ on the variation in the AFS was $16.2 \%$. But according to regression equation $13, \mathrm{C}_{18: 0}$ made no contribution to the aroma and flavor of Afyon Kaymagı.

Whilse the effect of both lactic acid and carbonyl compounds on the AFS of Afyon Kaymagı was $45.5 \%$, $(P<0.05)$, the individual effect of lactic acid was $40.0 \%(P<0.05)$. Lactic acid was the second most important compound for the aroma and flavor of Afyon Kaymagı. But AFS was negatively corellated with lactic acid. With the increase in the level of lactic acid comes a decline in the satisfactory aroma and flavor of Afyon Kaymagı.

The obtained regression equation for AFS demonstrated that the effect of carbonyl compounds on AFS was only $3.2 \%$. The total effect of carbonyl compounds was not significant $(P>0.05)$. 
Table 7

Results from the path analysis including the investigated compounds

\begin{tabular}{|c|c|c|c|}
\hline Variables & Regression equation & $\mathbf{R}^{2}$ & $\mathbf{P}$ \\
\hline Equation 1 for all compounds & $\begin{array}{l}\text { AFS }=-0.18 \mathrm{LA}+0.12 \mathrm{AA}-0.374 \mathrm{AC}-0.16 \mathrm{BU}- \\
0.093 \mathrm{DC}-1.94 \mathrm{C}_{4: 0}+2.83 \mathrm{C}_{6: 0}-0.569 \mathrm{C}_{8: 0}+1.53 \mathrm{C}_{10: 0} \\
-2.40 \mathrm{C}_{12: 0}+0.13 \mathrm{C}_{14: 0}+0.664 \mathrm{C}_{16: 0}-0.673 \mathrm{C}_{18: 0}- \\
0.403 \mathrm{C}_{18: 1}+0.683 \mathrm{C}_{18: 2}+0.248 \mathrm{C}_{18: 3}\end{array}$ & 0.933 & 0.00 \\
\hline Equation 2 for Free fatty acids & $\begin{array}{l}\mathrm{AFS}=-1.96 \mathrm{C}_{4: 0}+2.70 \mathrm{C}_{6: 0}+0.302 \mathrm{C}_{8: 0}+0.43 \mathrm{C}_{10: 0} \\
-1.85 \mathrm{C}_{12: 0}-0.087 \mathrm{C}_{14: 0}+0.462 \mathrm{C}_{16: 0}-0.28 \mathrm{C}_{18: 0}- \\
0.336 \mathrm{C}_{18: 1}+0.471 \mathrm{C}_{18: 2}+0.312 \mathrm{C}_{18: 3}\end{array}$ & 0.829 & 0.00 \\
\hline $\begin{array}{l}\text { Equation } 3 \text { for Lactic acid+carbonyl } \\
\text { compounds }\end{array}$ & $\begin{array}{l}A F S=-0.763 L A+0.118 A A-0.116 A C+0.167 B U \\
+0.128 D C\end{array}$ & 0.455 & 0.014 \\
\hline Equation 4 for carbonyl compounds & $\mathrm{AFS}=-0.08 \mathrm{AA}-0.066 \mathrm{AC}-0.016 \mathrm{BU}-0.087 \mathrm{DC}$ & 0.32 & 0.942 \\
\hline Equation 5 for Lactic acid & $\mathrm{AFS}=-0.632 \mathrm{LA}$ & 0.40 & 0.00 \\
\hline Equation 6 for $\mathrm{C}_{4: 0}$ & $A F S=-0.167 C 4$ & 0.28 & 0.397 \\
\hline Equation 7 for $\mathrm{C}_{6: 0}$ & $\mathrm{AFS}=-0.096 \mathrm{C} 6$ & 0.09 & 0.625 \\
\hline Equation 8 for $\mathrm{C}_{8: 0}$ & $\mathrm{AFS}=-0.35 \mathrm{C} 8$ & 0.122 & 0.068 \\
\hline Equation 9 for $\mathrm{C}_{10: 0}$ & $A F S=-0.403 C 10$ & 0.162 & 0.034 \\
\hline Equation 10 for $\mathrm{C}_{12: 0}$ & $A F S=-0.263 C 12$ & 0.69 & 0.177 \\
\hline Equation 11 for $\mathrm{C}_{14: 0}$ & $A F S=-0.174 C 14$ & 0.30 & 0.375 \\
\hline Equation 12 for $\mathrm{C}_{16: 0}$ & $\mathrm{AFS}=+0.098 \mathrm{C} 16$ & 1.00 & 0.619 \\
\hline Equation 13 for $\mathrm{C}_{18: 0}$ & $A F S=-0.008 C 18$ & 0.00 & 0.968 \\
\hline Equation 14 for $\mathrm{C}_{18: 1}$ & $A F S=-0.339 C 18: 1$ & 0.115 & 0.078 \\
\hline Equation 15 for $\mathrm{C}_{18: 2}$ & $A F S=-0.343 C 18: 2$ & 0.117 & 0.074 \\
\hline Equation 16 for $C_{18: 3}$ & $\mathrm{AFS}=-0.064 \mathrm{C} 18: 3$ & 0.04 & 0.747 \\
\hline
\end{tabular}

\section{CONCLUSIONS}

The results obtained from this study on some carbonyl compounds and the free fatty acid composition of Afyon Kaymagı present important information regarding the aroma and flavor of Afyon Kaymagı, about which no information is currently available. Therefore this is the first scientific study presenting an analysis of acetaldehyde, acetone, butanone-2, diacetyl and free fatty acids in Afyon Kaymagı produced from buffalo milk.

The results indicated that the amount of some carbonyl compounds and the free fatty acid composition were generally different from other dairy products. While free fatty acids were the main compounds which contribute to the aroma and flavor, carbonyl compounds did not have a significant effect. Acetone was the predominant carbonyl compound. Butyric acid, palmitic acid, stearic acid and oleic acid within the free fatty acid compositions were the predominant free fatty acids in Afyon Kaymagı. Thus to reduce the level of mould spoilage of the product by lipase-producing species, improved sanitation and control of air in the dairy plant should be used in the manufacturing of Afyon Kaymagı.

\section{REFERENCES}

Abd Rabo FH, Ahmed NS, Abou Dawood AE, Hassan FAM. 1992. Changes in milk constituents during the manufacture of Goat's milk yoghurt. Eqyptian J. Dairy Sci. 20, 317-328.

Avşar YK, Kılıç A, Yüceer Y, Evrendilek, GA, Atay-Avşar T. 2003. Bölgesel Süt Endüstrisinin Gelişiminde "Orjine Uygunluk" Sistemi ve Avrupa'daki Uygulamaları. GAP III. Tarım Kongresi 2-3 Ekim Şanlıurfa.

Amarjit SN, Toshihiko N. 2003. Role of buffalo in socio economic development of rural Asia: Current status and future prospectus. Anim. Sci. J., 74, 443-445.

Atamer M, Sezgin E. 1984. Tereyağlarında lipolitik ve okisdatif bozulmaların saptanmasında yararlanılan asit ve peroksid değerleri ile aroma arasındaki ilişki. Gıda Dergisi, 6, 329-334.

Atamer M, Gürsoy A, Öztekin Ş, Şenel E. 2004a. Determination of Some Carbonyl Compounds in Yayık Tereyağı. International Dairy Symposium. Recent Developments in Dairy Science and Technology, 174175 Isparta - Turkey

Atamer M, Şenel E, Öztekin Ş. 2004b. A traditional product: Yayık Tereyag conventional way of manufacturing and its some properties, International Dairy Symposium. Isparta Turkey, $149-152$

Atamer M, Şenel E, Öztekin FŞ. 2005. Yoğurttan Üretilen Tereyağlarının (Yayık Tereyağı) Bazı Niteliklerinin Belirlenmesi. TUBITAK, TOGTAG-3035, Ankara. 
Beshkova D, Simova E, Frengova G, Simov Z. 1998. Production of flavour compounds by yoghurt starter cultures. J. Ind. Mic. Biotech. 20, 180-186

Chaves ACSD, Fernandez M, Lerayer ALS, Mierau I, Leerebezem M, Hugenholtz J. 2002. Metabolic engineering of acetaldehyde production by Streptococcus thermophilus. Applied and Environmental Microbiology, November, 5656-5662.

Cousin MA 2003. Mould in Dairy Products. In: Roginski H. (Ed.) Encyclopedia of Dairy Sciences. Vol.3, Academic Press, An Imprint of Elsevier Science, California, 2072-2078.

Çon AH, Gökçe R, Gürsoy O. 2000. Farklı Şekillerde Ambalajlanan Afyon Kaymaklarının Muhafaza Sürelerinin Belirlenmesi Üzerine Bir Araștırma. Süt Mikrobiyolojisi ve Katkı Maddeleri, VI. Süt ve Süt Ürünleri Sempozyumu Tebliğler Kitabı, Tekirdağ, 557-566

Deeth HC, Fitz - Gerald CH, Snow AJ. 1983. A gas chromatographic method for the quantitative determination of free fatty acids in milk and milk products. New Zealand J. Dairy Sci.Tech. 18, 13-20

Draper NR, Smith H. 1998. Applied Regression Analysis. Third Edition John Wiley and Sons, NewYork

Frank JF, Marth EH. 1999. Fermantations in Wong NP. (Ed.) Fundamentals of Dairy Chemistry. Third Editon, An Aspen Publication, Maryland, pp.655-738

Fox PF, Guinee TP, Cogan TM, McSweeney PLH. 2000. Fundamentals of Cheese Chemistry. Aspen Publishers, Gaithersburg, Maryland

Formisano M, Percuoco G, Percuoco S. 1972. Microbiological investigation of fermented milk drinks. Gas chromatography of the fatty acids in yoghurt. Dairy Sci. Abst. 34, 1763.

Hooi R, Barbano DM, Bradley RL, Budde D, Bulthaus M, Chettiar M, Lynch J, Reddy R. 2004. Chemical and physical methods. In Wehr HM, Frank J.F. (Eds), Standard Methods for the Examination of Dairy Products. American Public Health Association, Washington DC, 363-532

IDF, 1981. Determination of The $\mathrm{pH}$ of The Serum. IDF Standard 104. Brussels, Belgium: International Dairy Federation

Kranenburg R, Kleerebezem M, Vlieg JH, Ursing BM, Boekrost J, Smit BA, Ayad EHE, Smit G, Siezen R. 2002. Flavour formation from amino acids by lactic acid bacteria: predictons from genome sequence analysis. Int. Dairy J. 12, 111-121.

Marshall RT, Arbuckle WS. 2000. Ice Cream, Fifth edition, Gainthersburg, Maryland

Menendez S, Centono JA, Godinez R, Rodriguez-Otero JL. 2000. Effects of Lactobacillus strains on the ripening and organoleptic characteristics of ArzuaUlloa cheese. Int. J Food Microbiol. 59, 37-46.
Mulder H, Walstra P. 1974. The Milk Fat Globule. Emulsion science as applied to milk products and comparable foods, Centre for Agricultural Publishing and Documantation Wageningen, The Netherland

Rasic JL, Kurmann JA. 1978. Yoghurt: Scientific Grounds, Technology, Manufacture and Preparations. Published by the authors

Rosner B. 2006. Fundamentals of Biostatistics, sixth edition, Thomson Higher Education 10 Davis Drive, Belmont, CA, USA

Siriken B, Erol i. 2009. Microbiological and Chemical Quality of Afyon Clotted Cream. J. Anim. Vet. Adv. 8, 2022-2026

Spreer E. 1998. Milk and Dairy Products Technology. Marcel Decker Inc. New York.

Steinsholt K, Calbert HE. 1960. A rapid colorimetric method for the determination of lactic acid in milk and milk products. Milhwissenschaft 15, 7-11

Senel E. 2000. A study on the use of a biopreservative culture using for keeping microbiological quality of yoghurt, Ankara University Graduate School of Natural and Applied Scineces, Department of Dairy Technology, Master Thesis, Ankara.

Senel E. 2006. The effect of some production parameters on Yayık butter produced from yoghurt. Ankara University Graduate School of Natural and Applied Sciences Department of Dairy Technology, Ph. D. Thesis, Ankara

Şenel E, Kocabaş Z, Öztekin FŞ, Atamer M. 2009. An invesitigation on some compounds effecting aroma and flavor of strained yoghurt produced from goat milk. Tarım Bilimleri - J. Agricul. Sci. 15, 363-370

Şenel E, Atamer M, Öztekin FŞ. 2011. The oxidative and lipolytic stability of Yayık Butter produced from different species of mammals milk (Cow, Sheep, Goat) yoghurt. Food Chem. DOI: 10.1016/ jfoodchem.2011.01.012

Ulbert F. 1991. Head Space Gas Chromatographic Estimation of Some Yoghurt Volatiles. J. Assoc. Off. Anal. Chem. 74, 630- 634

Vedamuthu ER. 2006. Starter cultures for yoghurt and feremented milk, In: Chandan $\mathrm{RC}$, White $\mathrm{CH}$ Kilara A, Hui YH (Eds). Manufacturing Yoghurt and Fermented Milks, 89-116

Tamime AY, Robinson RK. 2007. Tamime and Robinson's Yoghurt, Science and Technology, Third edition, Woodhead Publishing Limited, Abington Hall, Abington, Cambridge CB21 6AH, England

Tekinşen KK, Gürler Z. 2004. Afyon Kaymağı üretim teknolojisi ve kalite özellikleri. Türk Tarım, Tarım ve Köyişleri Bakanlığı Dergisi, 158, 60-62

Recibido: 28/1/11 Aceptado: $28 / 3 / 11$ 